\title{
Nowe możliwości terapeutyczne w cukrzycy typu 2 - praktyczne zastosowanie inhibitora SGLT2 na przykładzie kanagliflozyny
}

\author{
Novel therapeutic option in type 2 diabetes patients - practical experience \\ with canagliflozin, SGLT2 inhibitor
}

\section{STRESZCZENIE}

Zalecenia Kliniczne Polskiego Towarzystwa Diabetologicznego od 2014 roku uwzględniają możliwość zastosowania preparatu z grupy inhibitorów kotransportera sodowo-glukozowego 2 (SGLT2) w leczeniu skojarzonym z innymi lekami przeciwhiperglikemicznymi. Niniejsza praca stanowi prezentację dwóch przypadków klinicznych, w których do uprzednio stosowanej terapii dołączono inhibitor SGLT2 (kanagliflozynę). Pierwszy opis przypadku dotyczy chorego z niedostatecznie kontrolowaną cukrzycą typu 2 z towarzyszącymi: otyłością, nadciśnieniem oraz zaburzeniami lipidowymi. Ze względu na profil pacjenta zdecydowano o dołączeniu — do terapii insuliną i metforminą — kanagliflozyny, dzięki czemu uzyskano poprawę kontroli glikemii, redukcję masy ciała, a także, co istotne, zmniejszenie dawek insuliny. W przypadku drugiej chorej do monoterapii metforminą dołączono kanagliflozynę, uzyskując poprawę kontroli glikemii i redukcję masy ciała, co pozytywnie wpłynęło na jej motywację do dalszego leczenia. Dzięki mechanizmowi działania wykorzystującemu jako narząd docelowy nerkę, a nie trzustkę, możliwe jest kojarzenie inhibitorów SGLT2 z praktycznie wszystkimi dostępnymi obecnie terapiami przeciwhiperglikemicznymi u pa-

Adres do korespondencji:

lek. Alicja Milczarczyk

Klinika Chorób Wewnętrznych, Endokrynologii i Diabetologii

Centralnego Szpitala Klinicznego MSW w Warszawie

e-mail: milczarczyk.amp@poczta.onet.pl

Diabetologia Kliniczna 2015, tom 4, 5, 204-209

DOI: $10.5603 /$ DK.2015.0024

Nadesłano: 05.11.2015

Przyjęto do druku: 18.11.2015 cjentów na różnych etapach rozwoju cukrzycy typu 2. (Diabet. Klin. 2015; 4, 5: 204-209)

Słowa kluczowe: inhibitor transportera sodu i glukozy typu 2, kanagliflozyna, cukrzyca typu 2, kontrola glikemii, redukcja masy ciała

\section{ABSTRACT}

Sodium glucose co-transporter 2 inhibitors (SGLT2i) were introduced into Polish Diabetes Association Clinical Guidelines in 2014 in combination with other antihyperglycemic agents. In our paper we describe clinical cases of using SGLT2 inhibitor - canagliflozin as an add-on therapy in two different combinations. The first case refers to the patient with inadequately controlled type 2 diabetes, associated with obesity, hypertension and dyslipidemia. Due to the profile of the patient it was decided to add canagliflozin to insulin therapy and metformin, which resulted in improvements in glycemic control, body weight reduction, as well as reduction in insulin dose. In the second patient treated with metformin in monotherapy, addition of canagliflozin was associated with improved glycemic control and reduced body weight, which positively affected patient's motivation to continue treatment. Through the mechanism of targeting kidney instead of pancreas it is possible to combine this group of drugs with virtually all currently available antihyperglycemic treatments and in patients at various stages of type 2 diabetes. (Diabet. Klin. 2015; 4, 5: 204-209)

Key words: sodium glucose co-transporter 2 inhibitor, canagliflozin, type 2 diabetes, glycemic control, body weight reduction 


\section{Opis przypadku 1}

Alicja Milczarczyk

Mężczyzna w wieku 59 lat z cukrzycą typu 2 zgłosił się na wizytę do Poradni Cukrzycowej z objawami hiperglikemii. Chory skarżył się na wzmożone pragnienie, wysychanie w ustach, zmęczenie, senność oraz częstomocz. W wynikach samokontroli stężenie glukozy wynosiło do 270 mg/dl, a oznaczona w gabinecie wartość hemoglobiny glikowanej $\left(\mathrm{HbA}_{1 \mathrm{c}}\right) 11,9 \%$.

Chory pracuje, jest właścicielem restauracji. Nikt w jego rodzinie nie chorował na cukrzycę, natomiast obydwoje rodzice byli otyli. Od dzieciństwa miał nadwagę, przyrost masy ciała postępował wraz z wiekiem, największy nastąpił po zaprzestaniu palenia tytoniu w 44. roku życia, kiedy to chory przybrał na wadze około 12 kg w ciągu 6 miesięcy. Mężczyzna podejmował wielokrotne, nieskuteczne próby redukcji masy ciała. Cukrzyca została rozpoznana przed 14 laty przypadkowo w czasie badań profilaktycznych. Stwierdzono wówczas stężenie glukozy na czczo 112-126 mg/dl. Wykonano doustny test obciążenia 75 g glukozy (OGTT, oral glucose tolerance test), w którym stwierdzono stężenie glukozy na czczo 125 mg/dl, po 2 godzinach od obciążenia $267 \mathrm{mg} / \mathrm{dl}$. Zalecono dietę, aktywność fizyczną oraz metforminę w dawce dobowej 1500 mg. Chory źle tolerował większe dawki pochodnej biguanidu, miał metaliczny smak w ustach, wzdęcia brzucha, luźne wypróżnienia. Ze względu na pogarszanie się kontroli glikemii dołączono pochodną sulfonylomocznika. W tym czasie chory nie był pod opieką Poradni Cukrzycowej, nie przestrzegał zaleceń dietetycznych, posiłki spożywał nieregularnie, miewał napady głodu w nocy. Pomiary glikemii wykonywał sporadycznie, głównie na czczo. W ciągu 9 lat przybrał na wadze około $12 \mathrm{~kg}$. W tym czasie podejmował kilka nieskutecznych prób redukcji masy ciała.

Przed 2 laty był hospitalizowany z powodu złej kontroli glikemii (wartość $\mathrm{HbA}_{1 c}$ wówczas wynosiła 12\%). Wdrożono insulinoterapię w skojarzeniu z metforminą XR 2000 mg. Początkowo dawka dobowa insuliny wynosiła 56 j., ale ze względu na nieosiąganie celów terapeutycznych stale rosła, przekraczając ostatecznie 100 j./dobę.

W wywiadach chory podawał nadciśnienie tętnicze, hipercholesterolemię oraz stłuszczenie wątroby, które były rozpoznane razem z cukrzycą przed 14 laty.
Przewlekle przyjmuje telmisartan $80 \mathrm{mg}$, hydrochlorotiazyd $25 \mathrm{mg}$, amlodypinę $10 \mathrm{mg}$ oraz atorwastatynę $20 \mathrm{mg}$. Od 2 lat leczy się z powodu depresji, przyjmuje citalopram w dawce $20 \mathrm{mg}$. Wole guzkowe obojętne rozpoznawane jest od 15 lat. Z powikłań cukrzycy obecna jest retinopatia nieproliferacyjna.

W badaniu przedmiotowym zwracały uwagę otyłość brzuszna [wskaźnik masy ciała (BMI, body mass index) 39,4 kg/m², obwód talii $129 \mathrm{~cm}$ ] oraz podwyższona wartość ciśnienia tętniczego 170/90 mm Hg.

Wyniki badań dodatkowych, poza nieprawidłową wartością $\mathrm{HbA}_{1 c}(11,9 \%)$, ujawniły zaburzenie lipidowe (cholesterol całkowity $189 \mathrm{mg} / \mathrm{dl}$, cholesterol frakcji HDL 45 mg/dl, cholesterol frakcji LDL 103 mg/dl, triglicerydy $207 \mathrm{mg} / \mathrm{dl}$ ), szacunkowy współczynnik filtracji kłębuszkowej (eGFR, estimated glomerular filtration rate) $83 \mathrm{ml} / \mathrm{min}$, a wyniki samokontroli - hiperglikemię na czczo i poposiłkową przy stosowaniu insuliny w dawce dobowej 108 j. w skojarzeniu z metforminą XR 2000 mg. Wyniki samokontroli przedstawiono w tabeli 1.

Rozważając różne opcje terapeutyczne [dołączenie leku inkretynowego, akarbozy, inhibitora kotransportera sodowo-glukozowego 2 (SGLT2, sodium glucose co-transporter 2)] mające na celu poprawę wyrównania metabolicznego bez zwiększonego ryzyka wystąpienia hipoglikemii i przyrostu masy ciała, brano pod uwagę liczne problemy kliniczne występujące u chorego. Były to - poza złą kontrolą metaboliczną i obecnością retinopatii nieproliferacyjnej — otyłość brzuszna i związana z nią insulinooporność, której skutkiem była konieczność podawania choremu insuliny w dawce dobowej przekraczającej 100 j. Brano także pod uwagę małą skuteczność interwencji behawioralnej ze względu na tryb życia (nieregularne spożywanie posiłków, jedzenie w nocy, stres związany z wykonywanym zawodem, ograniczenia aktywności fizycznej wynikające z otyłości i depresji). Do stosowanej terapii insuliną i metforminą dołączono kanagliflozynę $w$ dawce dobowej $100 \mathrm{mg}$. Przed rozpoczęciem leczenia przedstawiono choremu w przystępny sposób mechanizm działania nowego leku oraz poinformowano go o możliwych działaniach niepożądanych wynikających z obecności glukozy w moczu. Omówiono również zasady higieny niezbędne do zminimalizowania ryzyka wystąpienia działań niepożądanych.

Tabela 1. Wyniki samokontroli przy stosowaniu insuliny: przed śniadaniem 20-22 j. analogu szybkodziałającego, przed obiadem 18-22 j. analogu szybkodziałającego, przed kolacją 24-28 j. analogu szybkodziałającego, przed snem 36 j. analogu długodziałającego oraz metformina XR $2000 \mathrm{mg} 1 \times 1 \mathrm{tabl}$.

\begin{tabular}{|c|c|c|c|c|c|c|c|c|c|}
\hline Godz. & 7.30 & 10.30 & 12.00 & 14.00 & 16.00 & 18.00 & 22.00 & 24.00 & 3.30 \\
\hline$[\mathrm{mg} / \mathrm{dl}]$ & 198 & 176 & 199 & & 218 & & 239 & 270 & 193 \\
\hline
\end{tabular}


Tabela 2. Wyniki samokontroli przy stosowaniu insuliny: przed śniadaniem 14-16 j. analogu szybkodziałającego, przed obiadem 12-14 j. analogu szybkodziałającego, przed kolacją 18-20 j. analogu szybkodziałającego, przed snem 24 j. analogu długodziałającego oraz metformina XR 2000 mg $1 \times 1$ tabl. i kanagliflozyna $300 \mathrm{mg} 1 \times 1$ tabl.

\begin{tabular}{lccccccccc}
\hline Godz. & 7.30 & 10.30 & 12.00 & 14.00 & 16.00 & 18.00 & 22.00 & 24.00 & 3.30 \\
\hline$[\mathrm{mg} / \mathrm{dl}]$ & 123 & 151 & 109 & & 144 & & 177 & 120 & 113 \\
\hline
\end{tabular}

Zastosowane leczenie pozwoliło uzyskać poprawę wyrównania metabolicznego. W samokontroli prowadzonej przez chorego obserwowano obniżenie glikemii na czczo (120-150 mg/dl) oraz poposiłkowej (129-190 mg/dl), a wartość $\mathrm{HbA}_{1 c}$ obniżyła się do 9,2\%. W badaniu kontrolnym wartość eGFR wyniosła $79 \mathrm{ml} / \mathrm{min}$. Nie występowały niedocukrzenia, chory ubył na wadze 3 kg, uzyskano poprawę kontroli ciśnienia tętniczego bez konieczności intensyfikacji leczenia hipotensyjnego. Terapia była dobrze tolerowana, nie wystąpiły działania niepożądane leku. Ogólne samopoczucie chorego poprawiło się. Widząc efekty zastosowanej terapii, nabrał on motywacji do przestrzegania diety, zaczął systematycznie spożywać posiłki, wdrożył aktywność fizyczną (basen, jazda na rowerze). Zdecydowano o zwiększeniu dawki dobowej kanagliflozyny do 300 mg. Po 2 tygodniach chory zgłosił się z objawami grzybiczego zapalenia żołędzi prącia. Zastosowano leczenie ketokonazolem z dobrym efektem, zakażenie nie nawracało.

Wizyta kontrolna odbyła się po 3 miesiącach. Chory nie zgłaszał dolegliwości. Stosował się do zaleceń dietetycznych i utrzymywał systematyczną aktywność fizyczną. Rozpoczął też psychoterapię. W badaniach zwracała uwagę poprawa kontroli glikemii (wyniki samokontroli po 3 miesiącach przedstawiono w tabeli 2), obniżenie wartości $\mathrm{HbA}_{1 \mathrm{c}}$ do 7,9\% oraz redukcja dobowej dawki insuliny o 34 j. Chory nie miał niedocukrzeń, a jego masa ciała zmniejszyła się o $3 \mathrm{~kg}$. Ciśnienie tętnicze było dobrze kontrolowane. Zalecono kontynuowanie dotychczasowego leczenia i wyznaczono wizytę kontrolną w Poradni Cukrzycowej za 3 miesiące.

\section{Komentarz do opisu przypadku 1 \\ Edward Franek}

Dane z badań NATPOL wykazują, że częstość występowania cukrzycy w Polsce wzrasta. Z różnych źródeł wynika, że w naszym kraju na cukrzycę choruje ponad 2 mln osób. Równocześnie wyrównanie metaboliczne cukrzycy pozostawia wiele do życzenia (nie tylko zresztą w Polsce). Przynajmniej częściowo przyczyną tego stanu rzeczy w naszym kraju jest fakt, że zarówno chorzy, jak i lekarze nie mają możliwości leczenia nowoczesnymi lekami (które nie są refundowane). Na szczęście ceny leków systematycznie spadają i wielu chorych w tej chwili może już sobie na takie nowoczesne leczenie pozwolić.

Jest to szczególnie ważne dla chorych stosujących insulinoterapię. W Polsce większość z nich otrzymuje dodatkowo tylko metforminę (ponieważ pochodne sulfonylomocznika w połączeniu z insuliną nie powodują większej poprawy glikemii, a zwiększają częstość niedocukrzeń). W przypadku złego wyrównania, pomijając środki niefarmakologiczne, jest zatem konieczne użycie któregoś z nowych leków przeciwcukrzycowych. W komentowanym przypadku została wybrana kanagliflozyna, jeden z inhibitorów transportera sodowo-glukozowego typu 2 (SGLT2). Kotransporter ten jest zlokalizowany w segmencie S1 cewki proksymalnej i odpowiada za wchłanianie zwrotne $90 \%$ przesączonej przez kłębuszek nerkowy glukozy. Zahamowanie jego aktywności skutkuje zwiększeniem wydalania glukozy (cukromoczem). Lek ten zmniejsza zatem dostępną w organizmie pulę glukozy, naśladując naturalny mechanizm obronny, występujący u chorych na cukrzycę, jakim jest cukromocz.

Badania kliniczne wskazują na skuteczność inhibitorów SGLT2 u chorych leczonych insuliną. Wynika to $z$ innego mechanizmu ich działania, który jest komplementarny do działania insuliny (i metforminy, którą omawiany chory otrzymywał). W omawianym przypadku pod wpływem leku u chorego doszło do obniżenia glikemii i wartości $\mathrm{HbA}_{1 \mathrm{c}^{\prime}}$ choć nie do wartości docelowych. Udało się także uzyskać redukcję dobowej dawki insuliny. W tym przypadku potwierdziły się zatem wyniki badań klinicznych, w których dokładnie takie efekty uzyskano u chorych leczonych insuliną, u których dołączono do terapii inhibitor SGLT2.

Wystąpiły jednak także objawy niepożądane - grzybicza infekcja prącia. Niezwykle ważne jest poinformowanie chorego o takiej możliwości, objawy zakażeń grzybiczych narządów płciowych nie są bowiem zwykle znane mężczyznom, a często przez nich stosowana taktyka „czekania, aż samo przejdzie” może prowadzić do stulejki i konieczności obrzezania chorego. Rozpoznane zakażenie grzybicze u chorych leczonych inhibitorem SGLT2 leczy się natomiast łatwo, a leczone nie daje powikłań i rzadko jedynie nawraca.

Komentując przypadek, należy zwrócić uwagę, że podawanie inhibitorów SGLT2 wiąże się także ze 
zwiększoną natriurezą i diurezą. Jest to zjawisko raczej korzystne, prowadzące do zmniejszenia się ciśnienia tętniczego, jednak może także skutkować objawami niepożądanymi związanymi z hipowolemią, takimi jak hipotonia ortostatyczna, omdlenia, spadek GFR itp. Zatem, decydując się na podanie leku u chorego z objawami niewyrównania cukrzycy (chory skarżył się na wzmożone pragnienie, suchość w ustach i tym podobne objawy odwodnienia), należy zachować ostrożność i odpowiednio nawodnić chorego przed rozpoczęciem leczenia.

Mówiąc o działaniach niepożądanych inhibitorów SGLT2, należy wspomnieć także o tym, że niedawno opisano kilkanaście przypadków normoglikemicznej kwasicy ketonowej stwierdzonej u chorych stosujących te leki. Właśnie z uwagi na normoglikemię lub stosunkowo niskie stężenia glukozy powikłanie to może być trudne do rozpoznania. Nie są na razie znane jego predyktory, nie wiadomo zatem, na jakich chorych należy zwracać szczególną uwagę. Aby go nie przeoczyć, należy zwracać pilną uwagę na objawy odwodnienia i pogorszenia się stanu ogólnego u chorych leczonych inhibitorami SGLT2 oraz oznaczać u nich parametry równowagi kwasowo-zasadowej i ciała ketonowe w moczu (względnie ich stężenia w surowicy).

Nie należy natomiast obawiać się hipoglikemii, jej ryzyko bowiem u chorych leczonych inhibitorami SGLT2 jest niskie. Stosowanie leków takich jak inhibitory SGLT2, niepowodujących hipoglikemii, zwiększających diurezę i natriurezę, obniżających ciśnienie tętnicze i masę ciała, powinno być związane ze zmniejszeniem ryzyka sercowo-naczyniowego. Istotnie, w pierwszym opublikowanym badaniu oceniającym wpływ empagliflozyny na twarde punkty końcowe (badanie EMPA-REG) wykazano, że w trakcie 4 lat badania lek ten spowodował zmniejszenie śmiertelności sercowo-naczyniowej i ogólnej w porównaniu z grupą otrzymującą placebo. Jest to bardzo ważny wynik, stawiający empagliflozynę (ale i inne inhibitory SGLT2, nad którymi badania nie zostały jeszcze zakończone) w „czołówce” leków przeciwcukrzycowych. Można oczekiwać, że przyszłoroczne zalecenia leczenia cukrzycy, zarówno polskie, jak i europejskie oraz amerykańskie, będą zalecały empagliflozynę (i być może inne inhibitory SGLT2) jako preferowany lek drugorzutowy (dołączany do metforminy) i trzeciorzutowy.

\section{Opis przypadku 2}

\section{Edyta Cichocka}

Pacjentka w wieku 62 lat ze stwierdzoną od 6 lat cukrzycą typu 2 zgłosiła się na kolejną wizytę do Poradni Diabetologicznej z powodu narastającego pogorszenia wyrównania glikemii. Dotychczas leczono ją metformi-
Tabela 3. Profil glikemii w samokontroli podczas stosowania metforminy w dawce $3 \times 1000 \mathrm{mg}$

\begin{tabular}{lccc}
\hline Na czczo & $\begin{array}{c}\mathbf{2} \text { godz. } \\
\text { po śniadaniu }\end{array}$ & $\begin{array}{c}\mathbf{2} \text { godz. } \\
\text { po obiedzie }\end{array}$ & $\begin{array}{c}\mathbf{2} \text { godz. } \\
\text { po kolacji }\end{array}$ \\
\hline 180 & 170 & 190 & 150 \\
200 & 182 & 215 & 210 \\
165 & 156 & 197 & 188 \\
\hline
\end{tabular}

ną, początkowo w dawce dobowej 1500 mg, aktualnie w dawce 3000 mg na dobę. Wartość HbA $_{1 c}$ wynosiła $7,9 \%$. Profil glikemii $w$ samokontroli przedstawiono w tabeli 3.

Wywiad chorobowy był dodatkowo obciążony nadciśnieniem tętniczym i stłuszczeniem wątroby. Chora na stałe przyjmowała ramipril w dawce $5 \mathrm{mg}$ na dobę i amlodypinę $5 \mathrm{mg}$ na dobę. Jak dotychczas nie stwierdzono przewlekłych powikłań cukrzycy.

Pacjentka prowadzi własną działalność gospodarczą (hurtownia materiałów biurowych). Jej praca ma głównie charakter siedzący, przy komputerze. Nie przestrzega zasad zdrowego żywienia. Ze względu na rodzaj pracy posiłki jada nieregularne, często poza domem. Nie podejmuje aktywności fizycznej, z wyjątkiem 2-3 spacerów tygodniowo. Nie pali od 5 lat, alkohol pija sporadycznie. Wywiad rodzinny obciążony cukrzycą typu 2 u mamy.

W badaniu przedmiotowym uwagę zwracała nadmiernie rozwinięta tkanka tłuszczowa okolicy brzucha. Masa ciała chorej wynosiła $78 \mathrm{~kg}$ (BMI $31 \mathrm{~kg} / \mathrm{m}^{2}$ ) - w ciągu ostatnich 12 miesięcy przybrała $5 \mathrm{~kg}$. Stwierdzono również podwyższone wartości ciśnienia tętniczego - 160/80 mm Hg. Poza tym bez istotnych odchyleń. $\mathrm{W}$ badaniach laboratoryjnych cholesterol całkowity wynosił 6,1 mmol/l, triglicerydy 2,4 mmol/l, a stężenie kreatyniny w surowicy krwi 85 umol/l (eGFR wg MDRD $63 \mathrm{ml} / \mathrm{min} / 1,73 \mathrm{~m}^{2}$ ). Nie obserwowano odchyleń w badaniu ogólnym moczu. Czynność wątroby: AIAT 52 U/l, AspaAT 74 U/l.

W wykonanym badaniu ultrasonograficznym jamy brzusznej uwidoczniono wątrobę o wzmożonej stłuszczeniowej echogeniczności. W badaniu neurologicznym wykazano osłabione odruchy kolanowe. Zapis EKG był prawidłowy.

Rozważając intensyfikację leczenia u prezentowanej pacjentki, brano pod uwagę dołączenie pochodnej sulfonylomocznika, inhibitora dipeptydylopeptydazy 4 (DPP-4), agonisty receptora dla glukagonopodobnego peptydu 1 (GLP-1, glucagon-like peptide-1), inhibitora SGLT2, a nawet insuliny. Omówiono z chorą wszystkie opcje terapeutyczne. Idealny lek dla przedstawionej pacjentki powinien być podawany doustnie, skutecznie 
Tabela 4. Profil glikemii w samokontroli podczas stosowania metforminy w dawce $3 \times 1000 \mathrm{mg}$ i kanagliflozyny $1 \times 100 \mathrm{mg}$

\begin{tabular}{lccc}
\hline Na czczo & $\begin{array}{c}\mathbf{2} \text { godz. } \\
\text { po śniadaniu }\end{array}$ & $\begin{array}{c}\mathbf{2} \text { godz. } \\
\text { po obiedzie }\end{array}$ & $\begin{array}{c}\mathbf{2} \text { godz. } \\
\text { po kolacji }\end{array}$ \\
\hline 106 & 150 & 120 & 130 \\
112 & 160 & 144 & 120 \\
125 & 150 & 150 & 110 \\
\hline
\end{tabular}

i długotrwale poprawiać kontrolę glikemii, wpływać korzystnie na masę ciała, redukować ciśnienie tętnicze i wykazywać niskie ryzyko hipoglikemii i działań niepożądanych.

Przeprowadzono reedukację dietetyczną, zalecono zwiększenie aktywności fizycznej, zachęcając pacjentkę do rozpoczęcia regularnego uprawiania nordic walking.

Zmodyfikowano dotychczasową terapię, dołączając kanagliflozynę w dawce 100 mg na dobę. Dołączono także atorwastatynę $20 \mathrm{mg}$ wieczorem i zintensyfikowano leczenie hipotensyjne, zwiększając dawkę ramiprilu do $10 \mathrm{mg}$. Chorą poinformowano o potencjalnych działaniach niepożądanych kanagliflozyny, wynikających z glukozurii. Zalecono przestrzeganie odpowiednich zasad higieny w celu uniknięcia infekcji układu moczowo-płciowego.

Pacjentka zgłosiła się na kontrolną wizytę do Poradni Diabetologicznej po upływie 3 miesięcy, sygnalizując dobre samopoczucie. Zastosowała się do zaleceń dietetycznych i zwiększyła aktywność fizyczną. Zaobserwowano spadek masy ciała o $3 \mathrm{~kg}$ (aktualnie masa ciała pacjentki wynosiła $75 \mathrm{~kg}$ ). Poza zwiększeniem diurezy, zwłaszcza w pierwszym miesiącu leczenia, nie zgłaszała działań niepożądanych rozpoczętej terapii inhibitorem SGLT2. Wartości ciśnienia tętniczego uległy normalizacji (130-140/80 mm Hg). Zastosowane leczenie wpłynęło na poprawę glikemii w samokontroli, nie obserwowano incydentów hipoglikemii (tab. 4).

W badaniach dodatkowych $\mathrm{HbA}_{1 \mathrm{c}}$ obniżyła się do wartości 7,3\%. Kontrolne stężenie kreatyniny w surowicy krwi wynosiło 80 umol/l (eGFR wg MDRD $68,0 \mathrm{ml} / \mathrm{min} / 1,73 \mathrm{~m}^{2}$ ). W badaniu ogólnym moczu oprócz glukozurii $(++)$ nie stwierdzono odchyleń. Zalecono zwiększenie dawki kanagliflozyny do $1 \times 300 \mathrm{mg}$ na dobę oraz utrzymano dotychczasową dawkę metforminy.

Po kolejnych 3 miesiącach wystąpił dalszy spadek masy ciała - chora schudła $1 \mathrm{~kg}$ od ostatniej wizyty (łącznie 4 kg), co szczególnie motywowało ją do kontynuacji leczenia. Kontrolne ciśnienie tętnicze wynosiło 110/80 mm Hg, $\mathrm{HbA}_{1 \mathrm{c}} 7,0 \%$, cholesterol całkowity $4,9 \mathrm{mmol} / \mathrm{l}$, triglicerydy $1,7 \mathrm{mmol} / \mathrm{l}$. Pogorszyła się
Tabela 5. Profil glikemii w samokontroli podczas stosowania metforminy w dawce $3 \times 1000 \mathrm{mg}$ i kanagliflozyny $1 \times 300 \mathrm{mg}$

\begin{tabular}{lccc}
\hline Na czczo & $\begin{array}{c}\mathbf{2} \text { godz. } \\
\text { po śniadaniu }\end{array}$ & $\begin{array}{c}\mathbf{2} \text { godz. } \\
\text { po obiedzie }\end{array}$ & $\begin{array}{c}\mathbf{2} \text { godz. } \\
\text { po kolacji }\end{array}$ \\
\hline 95 & 115 & 120 & 144 \\
102 & 133 & 160 & 132 \\
108 & 132 & 146 & 110 \\
\hline
\end{tabular}

jednak funkcja nerek i obniżył wskaźnik przesączania kłębuszkowego (kreatynina 102 umol/l, eGFR wg MDRD $52 \mathrm{ml} / \mathrm{min} / 1,73 \mathrm{~m}^{2}$ ). Zmodyfikowano terapię i zmniejszono dawkę kanagliflozyny do $1 \times 100 \mathrm{mg}$ na dobę (przy obniżeniu eGFR $<60 \mathrm{ml} / \mathrm{min} / 1,73 \mathrm{~m}^{2}$ można kontynuować stosowanie leku po uprzedniej redukcji dawki do 100 mg/dobę), zmniejszono również dawkę ramiprilu do $1 \times 5 \mathrm{mg}$ na dobę i zalecono wczesną kontrolę wydolności nerek. Nie obserwowano działań niepożądanych ze strony układu moczowo-płciowego. Nie było również incydentów hipoglikemii. Wyniki samokontroli przedstawiono w tabeli 5 .

\section{Komentarz do opisu przypadku 2}

Janusz Gumprecht

Cukrzyca, pomimo prowadzonych na coraz szerszą skalę działań prewencyjnych, pozostaje schorzeniem stanowiącym istotny problem społeczny, który nabiera rosnącego znaczenia zarówno z klinicznego, jak i epidemiologicznego punktu widzenia, a dążenie do indywidualnie określonego celu terapeutycznego, poza normalizacją podwyższonych wartości ciśnienia tętniczego oraz współistniejących zaburzeń gospodarki lipidowej i masy ciała, ma kluczowe znaczenie w terapii.

Pierwszym etapem leczenia cukrzycy powinna być monoterapia, która obejmuje modyfikację stylu życia w połączeniu z metfominą. W przypadku nietolerancji metforminy, nasilonych działań niepożądanych lub przeciwwskazań do jej podawania możliwe jest stosowanie pochodnych sulfonylomocznika lub inhibitorów dipeptydylopeptydazy 4 (DPP-4), lub inhibitorów kotransportera sodowo-glukozowego typu 2 (SGTL2), lub agonisty receptorów gamma aktywowanych przez proliferatory peroksysomów (PPAR- $\gamma$ ). Z punktu widzenia pacjenta optymalna terapia cukrzycy powinna opierać się na prostym schemacie, lekach skutecznych i bezpiecznych oraz pozbawionych działań niepożądanych.

Z uwagi jednak na progresywny przebieg choroby i stopniowe pogarszanie czynności komórek $\beta$ wysp trzustkowych kontrola glikemii nadal pozostaje trudna i stymuluje do poszukiwania nowych kierunków i możliwości efektywnej terapii. Drugim zatem etapem 
leczenia jest leczenie skojarzone z uwzględnieniem terapii dwulekowej, które obejmuje modyfikację stylu życia i dołączenie do metforminy pochodnej sulfonylomocznika lub leku inkretynowego (inhibitora DDP-4 lub agonisty receptora GLP-1), lub inhibitora SGLT-2, lub agonisty PPAR- $\gamma$.

Szczególnie interesujące $w$ tym ujęciu, obok terapii inkretynowej, wydaje się zastosowanie, jak w opisywanym przypadku, inhibitora SGLT2, ponieważ leki te, wpływając na zmniejszenie reabsorpcji zwrotnej glukozy w nerkach i zwiększając tym samym jej wydalanie z moczem, działają w sposób niezależny od insuliny, zarówno pod względem jej wydzielania, jak i samego działania. Tym samym stopień nasilenia współistniejącej insulinooporności i/lub związana z progresywnym charakterem choroby postępująca dysfunkcja komórek $\beta$ wysp trzustki nie wpływają na efektywność terapii, co daje możliwość dodatkowego, korzystnego i długotrwałego wpływu inhibitorów SGLT2 na wyrównanie glikemii, niezależnie od stadium zaawansowania historii naturalnej cukrzycy typu 2, w którym znajduje się pacjent. Leki te, również w terapii skojarzonej z metforminą, poprawiają wyrównanie metaboliczne cukrzycy w sposób zależny od dawki, przejawiające się obniżeniem wartości $\mathrm{HbA}_{1 \mathrm{c}^{\prime}}$ glikemii na czczo oraz glikemii poposiłkowej. Szczególnie godny podkreślenia jest ponadto fakt możliwości uzyskiwania powyższego efektu bez wzrostu ryzyka wystąpienia epizodów hipoglikemii, w połączeniu z jednoczesnym spadkiem masy ciała oraz korzystnym wpływem na wartości ciśnienia tętniczego. Obserwowane w dotychczasowych badaniach działania niepożądane, powiązane z mechanizmem działania tej klasy leków, a obejmujące głównie wzrost ryzyka infekcji dróg moczowo-płciowych, zwłaszcza w początkowym okresie leczenia i szczególnie w populacji kobiet, wymagają dalszych badań. Co ważne, ich nasilenie w zdecydowanej większości przypadków jest łagodne lub co najwyżej umiarkowane, łatwo poddaje się standardowemu leczeniu, wyjątkowo tylko będąc przyczyną dyskontynuacji leczenia, a zatem w chwili obecnej nie wydaje się, by ograniczały możliwości stosowania inhibitorów SGLT2 jako nowej, obiecującej terapii cukrzycy typu 2. 